\title{
Vladimir Propp'un Masal Anlatısı Perspektifinden “Interstellar" Filminin İncelenmesi
}

\author{
Bayram Çăglar ${ }^{1}$
}

\begin{abstract}
Öz
Bu çalışmada, günümüz dünya sinemasını domine eder konumda bulunan Hollywood film endüstrisinin, 2014 yılında neredeyse tüm dünyada gösterime soktuğu ve üzerine yoğun 'bilimsel' ve popüler tartışmaların yapıldığı "Interstellar", Türkçe adıyla "Yıldızlarası", filminin çağdaş bir masal olup olmadığı tartışılmaktadır. Makalede söz konusu film, Rus biçimci ve halk bilimci Vladimir Propp'un 'masal anlatısı' konusunda geliştirdiği yöntem temel alınarak incelenmiş, 'Interstellar'ın çağdaş bir bilim-kurgu masalı olduğu tezi işlenmiştir. Yapısalcılık perspektifinden yapılan incelemede, V. Propp'un masal anlatısındaki 31 maddelik 'işlevselci' sıralaması tek tek filme uyarlanmıştır. Makale, filmin bu yönlü bir çözümlemesinden hareketle kurmaca anlatının, yüzlerce yıllık geçmişinden, mitolojiden masala, antik dramadan tiyatroya ve destandan romana kadar, çağdaş anlatı biçimlerinden sinemanın da beslendiği kaynağın müşterekliğine dikkat çekmektedir.
\end{abstract}

Anahtar Kelimeler: V.Propp, Interstellar filmi, yapısalcılık, peri masalı, bilim-kurgu

\section{The Examination of The Movie "Interstellar" From The Tale Narration Perspective Of Vladimir Propp}

\begin{abstract}
This paper discusses whether the movie "Interstellar", on which extensive "scientific" and popular discussion has been made and shown almost all around the world in 2014 by the Hollywood movie industry that rules over today's cinema globally, is a modern fairy tale or not. The movie in question has been examined based on the method developed by the Russian formalist and folklorist Vladimir Propp on the "tale narration" and defended that "Interstellar is a modern science-fiction tale in the paper. In the analysis conducted from the perspective of constructivism, "functionalist" rating of 31 articles in the novel narration of Propp has been adapted to the movie one by one. The article draws attention to the commonality of the source on which cinema feeds from the modern narration forms from mythology to tale, ancient drama to theatre and saga to novel for the hundreds of years of history of fiction with reference to the analysis of the movie in this perspective.
\end{abstract}

Key Words: V.Propp, Interstellar movie, constructivism, fairytale, science-fiction 


\section{Giriș}

$\mathrm{M}$ ahfuz Zariç (2013:117), Yaşar Kemal'in 'Ağrı Dağı Efsanesi' romanına yönelik yaptığı incelemede, yazarın beslendiği sözlü kültürün de etkisiyle eserde masal türünün kurgu özelliklerini taşıdığına dikkat çekmektedir. Zariç, adı geçen roman gibi başka eserleri de incelerken V.Propp'un 'masal izlencesi' yöntemini başarıyla uygulayarak, anlatı formunun genelliğine dikkat çeker. Bu yöntem birçok araşıırmacı tarafından çeşitli metinlere uygulanmış, başarılı sonuçlar elde edilmiştir. Hatta, Roland Barthes'ın, Propp'un yöntemini Hıristiyanlığın kutsal kitabı İncil'in Tekvin (yaratılış) bölümündeki bir parçaya uyguladığı da bilinmektedir (Yaren, 2013:183). Söz konusu yöntem, öykülü sinema filmlerinin çözümlemesinde de kullanılmaktadır.

Günümüzde sinema, insanlığın geçmişte masallar ve destanlar yoluyla yarattığı mitlerin işlevini dönüştürerek yeni 'masallar' ve 'destanlar' üretmektedir. Hollywood ticari öykülü sineması polisiyeden bilim-kurguya, korkudan psikolojik gerilime hayatın içinde olan ve akla gelebilecek her alanda film üretmeyi, bu üretim sürecinde insanlığın ortak birikimlerini birer 'malzeme' olarak kullanmayı temel araç haline getirmiştir. Interstellar filminde de bu unsurları görmek mümkündür. Bu bakımdan bilimsel, fantastik ve mantık dışı öncülleri de bulunan, 2014 yılında gösterime giren ABD-Birleşik Krallık (İngiltere) yapımı Interstellar filmi incelemeye değer görülmüştür. Sinema eleştirmenlerince çok kısa bir zamanda 'kült' sayılabilecek filmlere örnek olarak gösterilen bilim-kurgu türünüWn bu yeni örneği, bilim-kurgu, fantastik ve masal anlatısının benzerlikleri dikkat alınarak daha önce birçok öykülü filme uygulanmış olan Propp'un masal metinleri izlencesinden yararlanılarak analiz edilmiştir. Filmin çözümlemesinde Rus biçimci ve halk bilimci Propp'un peri masalları (olağanüstü masallar) izlencesinin işlevleri temel alınırken, A.J.Greimas'ın eyleyenler modellemesi ile R.Barthes'ın düz, derin ve yananlam yaklaşımı ve mitsel anlatıların özelliklerine de değinilmiştir. Çözümleme için Interstellar filminin seçilmesinin nedeni en son bilim-kurgu türlerinden biri olması ve bize göre masal anlatısının özelliklerini taşıdığı varsayımıyla ilgilidir. Çalışma, Hollywood ticari-eğlence sinemasının öykülü film anlayışı ve bilim-kurgu türü ile sınırlandırılmıştır.

\section{Nasıl Anlatıyoruz ve Anlamlandırıyoruz?}

Günümüz medya anlatı formları olan film senaryolarında, televizyondaki dizi ve reklamların öykülü anlatımlarında anlam üretilirken, çağdaş anlayışın ve algının dikkate alındığı; fakat, aynı zamanda insanlığın ortak hafızasına ya da çeşitli dini, mitolojik, destansı olaylara ve olgulara gönderme yapıldığı bilinen bir gerçekliktir. Bu işleyişin nesnel bir zorunluluktan kaynaklandığı, anlamı daha güçlü ve çarpıcı düzeye çıkardığı, hatta, bunun bazen amaçsal (teleolojik) bazen de farkında olmadan hayata geçirildiği belirtilmektedir. Alev Parsa (2013: 27) en çağdaş teknoloji ve en modern anlatı yapılarının görüldüğü sinema filmlerinde masalsı formüllerin bir senaryonun ana eksenini oluşturabildiğine dikkat çekmektedir. Bu bağlamda, günümüz anlatı formlarından biri olan öykülü filmin, arketipsel ve mitolojik karakterleri masallardan ödünç alarak onları dönüştürerek başkalaşıma uğrattığı gözlemlenmektedir. Öte yandan 'sıradan' sinema izleyicisi ve televizyon izler kitlesinin söz konusu masal ve mitolojik referanslar konusunda bilgi sahibi olmasa dahi günümüz formlarındaki anlatılardan geçmişteki insanlarda olduğu gibi etkilenmekte, anlatılar üzerinde düşünmekte, onu yeniden yorumlamakta ve başkalarına sözlü ya da yazılı olarak aktarmaktadır. Bu anlatılardaki anlamı ortaya koymak için yapısalcı ve göstergebilimsel çözümleme 
yapmak metinler üzerindeki sis perdesini aralamak için kullanılan yöntemlerden biridir. Göstergebilim yapısalcılığın bir biçimidir; tüm kültürler dünyayı anlamlandırırlar ve oluşturulan anlamlar kendilerine özgü olsa da anlamlandırmanın yolları evrenseldir. Anlamlar üretildikleri kültürlere özgüdür; ancak, bunları üretme biçimleri tüm insanlar için evrenseldir (Fiske, 2003:151-152). Bu yöntembilimsel çözümlemenin en önemli temsilcilerinden Roland Barthes göstergebilimin konusunun anlam olduğunu kesinlemiştir. Barthes, tüm gösterge dizgelerinin, örneğin, resimlerin, insan devinilerinin, katıldıkları tören ya da gösterilerin, yazın yapıtlarının, tiyatronun vb., birer anlamlama dizgesi oluşturduğunu söyler (Yücel, 2008:119). Anlam, özellikle yazılı metinlerde ilk yapısal çözümlemelere tabi tutulmuştur. Barthes (2012:158), anlatıyı, işlevi bir öyküden öbürüne aynı kalan dizgeli bir eylemler dizisi olarak ifade eder. Özellikle sözlü anlatılarla başlayıp daha sonra yazılı metinlere geçirilen masallardaki anlatı formu, metinlerdeki karakterler, edimlerin devamlıığını esas almıştır.

V.Propp, birkaç yüz Slav masalını çözümlediği çalışmasında masalın formunu kesin olarak oluşturan öğelerdeki kişiler ve eylemleri, eylemlerin dizilişini ve bunların sürekliliğini ortaya koymuştur. Esasında bu kesinlik çözümlemelerde nihai bir sonuç oluşturmaz. Barthes'ın (2012:159) da ifade ettiği gibi bunlar sadece birer şemadır. LeviStrauss ile Greimas gibi düşünürler bu taslağı geliştirip düzelterek yapılandırmıştır. Herhangi bir anlatıda eylemlerin önemli-önemsiz gibi ayrımlara tabi tutulması gibi bir lüks söz konusu değildir. Sözlü anlatıların tersine, metinde hiçbir söz özelliğinin anlamsız olmadığı, anlatıdaki eylemlerin ne kadar önemsiz görünürseler görünsünler, çözümlemeleri gerektiği ve betimlemeye uygun düşecek bir düzen içinde katılmaları gerektiği şüphesizdir. Örneğin, üzerinde çalışılan Interstellar filmindeki mısır tarlası (bitkisi), toz bulutları ve fırtınalar, Murphy kanunları, Morse alfabesi, Gargantua karadeliği, Lazarus görevi ve Satürn gezegeninin ifade ettiği anlamlar (kodlamalar), izler kitlece hakkında ister bilgi sahibi olunsun ister olunmasın çeşitli mesajlarla kodlanarak filme uyarlanmıştır.

Levi-Strauss'a göre, bir metnin çözümlemesi bize metnin görülmeyen anlamını ya da gizli anlamını verir. Ona göre, bir metin dizimsel ve dizisel olarak çözümlenir. Dizimsel çözümleme bize metnin ne olduğunu, dizisel çözümleme ise metnin ne anlama geldiğini söyler (Berger, 2014:105). Barthes (2012:108) ise bir anlatısal yapıtta üç betimleme düzeyi ayırt edilmesini önerirken, bunları Propp'un benimsediği 'işlevler', Greimas'ın anlatı kişilerinden 'eyleyenler' ve Todorov'un 'söylem' düzeyleri olarak kaydeder. Söz konusu süreç, bir 'işlev', bir 'eyleyenin' genel eylemi içinde yer aldığı ölçüde anlam kazanır; bu eylem de son anlamını, anlatılmış, kendine özgü kuralları (kodu) bulunan bir 'söyleme' bırakılmış olması nedeniyle kazanır, şeklinde ifade edilmektedir (Barthes, 2012:108). Özce, bir anlatıda işlev, eyleyen ve söylem anlamın ortaya çıkmasını sağlayan temel unsurlardır.

Interstellar'ı her ne kadar Propp'un masal işlevleri temelinde incelemeye tabi tutsak da filmin çok katmanlı senaryo yapısı nedeniyle göstergebilimsel yöntemin önerdiği 'düzanlam' ve 'yananlam' açısından da değerlendirmek çalışmanın amacına hizmet edecektir. Filmde özellikle Murphy kanunları, Morse alfabesi, mısır tarlaları, toz fırtınası, Lazarus görevi, Gargantua kara deliği ve Satürn çevresindeki solucan geçidi gibi simgesel kodlamaların insanlık ve özellikle de Amerikan tarihiyle yakından ilişkilendirilebileceği, olay örgüsünün şekillenişinde bu unsurların önemli kodlar oluşturduğu düşünülmektedir. Interstellar filmindeki göstergelerin, yan anlamlar 
düzeyinde yorumlanması bu açıdan önemli olmaktadır. Yananlam düzeyinin filmin temel mesajını oluşturduğu bir önkabul olarak değil, kesitlerin incelenmesiyle 'gerçeğin' açığa çıkarılmasına hizmet edeceği hipoteziyle yakından ilgilidir.

\section{Hollywood Bize Masal mı Anlatıyor?}

V.Propp (1995:207-208), olağanüstü masalın öbür masal sınıfları olan fıkralar, öyküler ve fablların tersine gerçek yaşama ilişkin öğeler bakımından görece yoksul olduğunu; masalın yaratılmasında gerçekliğin oynadığı rolün çoğunlukla abartıldığını söylemektedir. Sinema ve televizyon endüstrisi edebiyat dünyasından, halk hikâyelerinden, masallardan, mitolojik olaylardan ve destanlardan birçok ürünü film ve dizi film haline getirerek hem ticarileştirmekte hem de onları günümüz koşullarındaki insanların anlamlandırabileceği düzeye çekerek yeni bir anlam dünyası yaratmaktadır. Propp'un sözünü ettiği gerçekliğin abartılması Hollywood'un hikâyeleri şekillendirirken başvurduğu yollardan biridir. Hollywood sinema endüstrisi masalsı anlatılara daima önem vermiş filmlerde 'mitsel' ve 'arketipsel' kahramanlık formlarını teknolojinin kendisine sağladığı olanaklar sayesinde yeniden biçimlendirmeyi de inmal etmemiştir. Bağlamlarından kopartılan fakat insanlığın ortak belliğinde gerek yazılı gerekse sözlü olarak var olan unsurları yeni birer anlatı formuna dönüştürerek resimleştirip, hareketli fotoğraflar ve efektlerin de desteğiyle yeni masallar ve destanlar yaratmıştır.

Umberto Eco (1995:148), hiç kimsenin doğrudan şimdiki zamanın içinde yaşamadığını, hepimizin bireysel ve kolektif şeyleri ve olayları, belleğin birleştirici işlevi aracılığıyla derlediğimizi, ister mitler (mitoslar) olsun ister tarih, bireysel ve kolektif belleğin oluşturduğu bu karmaşık yapının, yalnız geriye doğru olsa da yaşamımızı uzattığını kaydetmektedir. Bu bakımdan masalların dini, mitolojik ve gerçek üstü olgularla bağıntılarının bulunabileceğini belirten Propp (1995:206-207), aynı zamanda tüm insanlığın, anlatılarının şekillenişinde benzer hayaller kurabileceğine dikkat çeker. $\mathrm{Bu}$ anlatım biçiminin kaçınılmazlığına günümüz öykülü sineması da dâhil edilmelidir. Öykülü filmlerin de bir çeşit anlatı formu olduğu düşünüldüğünde bu yapının biçimselliğinin ve olay örgülerinin Propp'un 'peri masalı' şemasına uygun olduğu gözlerden kaçmamaktadır. Filmlerdeki başrollerin ve yardımcı rollerin görevleri ya da işlevleri nasıl öyküde genel akışı sağlıyor ise Propp'un biçimbiliminin en belirgin özelliği de işlevlere verdiği önceliktir. Öyle ki, ona göre bu işlevler olmaz ise anlatı gerçekleşmemektedir. Yazar işlev sözcüğünden, eylem kesitlerini daha doğrusu eylemin soyut biçimlerini anlamaktadır. Propp, işlevlerin masallardaki karakterleri sürükleyen temel unsur olduğunu belirtirken, sınırıılıklarına da dikkat çeker.

\section{V.Propp ve Masal Çözümlemesi}

V.Propp, masal anlatısında kalkışta yani 'başlangıçta' yedi (7) işlev sıralamaktadır. Bunlar, uzaklaşma, yasaklama, yasağı çiğneme, soruşturma, bilgi toplama, aldatma ve suça katılma şeklindedir. Bu işlevler bütün masallarda çok sayıda somut niteliklere bürünerek, ama, aynı dizilişi izleyerek ortaya çıkar ve eylemleri yerine getiren kişilerden bağımsız olarak betimlenebilir (Ricceur, 2012:70). Masal anlatılarında kişiler işlevleri yerine getirmelerine göre kümelenirler her bir kişiye bir eylem alanı düşer. Böylece, eylem alanı kavramı da işlevlerin dağılımında yeni bir bireşim ilkesini işin içine katar (Ricceur, 2012:76-77). Paul Ricceur (2012:75) kişiler konusunda Propp'un yedi sınıf ayırt ettiğini de hatırlatır. Bunlar; saldırgan, bağışçı (ya da sağlayıcı), yardımcı, 
aranan kişi, gönderen, kahraman ve düzmece kahramandır. Propp, bu sınıflamadaki hiçbir işlevi bir anlatı kişisine bağlamadan tanımlamaz. Bu işlevlerin bazıları kimi anlatılarda yoktur; bazılarınınsa bir başka anlatıda yinelendikleri görülür. Modern metinleri çözümlerken Propp'un işlevleri kullanıldığında bazılarının güncelleştirmesi ve değiştirilmesi gerekebilmektedir (Berger, 2014:103). Arthur Berger (2014:103), modern metinler olarak sinema filmlerini örnek gösterir ve James Bond filmlerinden, TV'deki ulusal haberlere kadar masalın biçimbilimsel (morfolojik) çözümlemesinin bu şematik pratiğe çok rahat uygulanabileceğini ifade eder. Propp'un anlatı akışını saptadığı kurgu ve şeması dört ana bölümden oluşmaktadır:

\section{I.BAŞLANGIÇ DURUMU: Serim}

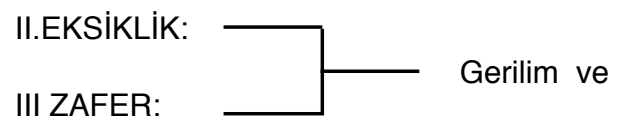

\section{IV.ORTAYA ÇIKARMA: Çözüm ve Mutlu Son}

Bu sıralama tüm anlatılarda, masallarda ve genellenirse öykülü anlatılarda, 1) Hazırlık, 2) Karışıklık, 3) Dövüş, 4) Dönüş ve 5) Tanınma bölümlerinden oluşmaktadır (Parsa, 2012:20). Bu bölümlerin anlatı içindeki oluş şekilleri ise şöyle ifade edilmektedir: Kahraman yaşamla uyum içindeyken bir eksikle karşılaşır, eksikliği gidermek için bir serüvene atılır ve yola çıkar. Kahraman yardımcıyla karşılaşır ve serüven için donatılır. Kahraman yolculuğu sırasında çeşitli serüvenlere ve savaşımlara girer. Kahraman eksikliği gidermek için büyülü nesneyi bulmuş olarak geri döner. Geri döndüğünde düzmece bir başka kahramanla karşılaşabilir ve onu alt eder. Kahraman ödüllendirilir. Mutlu son gerçekleşir. Mutlu son genellikle prensesle evlenme, kral olma şeklinde ortaya çıkar veya yeni bir eksiklik ortaya çıkar, öykü yinelenir (Akerson, 2005:138). Propp (1987:44), masal çözümlemesi gerçekleştirirken, işlevlere geçmeden önce bu tür metinlerin başlangıç aşamasının yer aldığını da belirtmiş, geri kalan 31 işlevi harfler, rakamlar ve sembollerle kodlamıştır. Bu kodlamaları başka benzer masallara (metinlere) uygulayarak genelleme yoluna gitmiştir. Propp'un işlevlerinin metinlere yönelik genelleştirmesine Interstellar filminin senaryosunu da dahil etmek gerekmektedir. Filmin anlatım özelliklerinin masal formatına uygun olduğunu da dikkatlerden kaçırmadan, konusu, karakterleri ve oyuncuları hakkında bilgi vermek çalışmanın temel amacına hizmet etmesi bakımından önemlidir.

\section{Interstellar Filminin Künyesi ${ }^{2}$}

Yönetmen: Christopher Nolan

Yapımcı: $\quad$ Emma Thomas, Christopher Nolan, Lynda Obst

Senarist: Jonathan Nolan, Christopher Nolan

Oyuncular: $\quad$ Matthew McConaughey, Anne Hathaway, Jessica Chastain, Michael Caine, Bill Irwin, Ellen Burstyn

Müzik: Hans Zimmer

Sanat Yönetmeni: Hoyte van Hoytema 


\begin{tabular}{|c|c|}
\hline Kurgu: & Lee Smith \\
\hline $\begin{array}{l}\text { Dağıtıcı: } \\
\text { arası) }\end{array}$ & Paramount Picture (Kuzey Amerika), Warner Bros. Picture (Uluslar \\
\hline Çıkış Tarihi: & $\begin{array}{l}26 \text { Ekim 2014(Prömiyer), } 05 \text { Kasım 2014(Kuzey Amerika), } 07 \text { Kasım } \\
\text { 2014(Birleşik Krallık, Türkiye) }\end{array}$ \\
\hline Süre: & 169 dakika \\
\hline Ülke: & ABD, Birleşik Kralık(UK) \\
\hline Dil: & İngilizce \\
\hline Bütçe: & 165 Milyon Dolar \\
\hline Hâsılat: & 663,3 Milyon Dolar \\
\hline
\end{tabular}

\section{Filmin Ana Karakterleri}

Astronot Ekibi: Matthew McConaughey(Cooper), Anne Hathaway (Amelia Brand), David Gyasi(Romilly),Wes Bentley, (Doyle), Bill Irwin( TARS seslendirmesi), Josh Stewart(CASE seslendirmesi).

\section{Diğer Karakterler}

Jessica Chastain (Murphy), Mackenzie Foy (Genç Murphy), Ellen Burstyn (Yaşı Murphy), Michael Caine ( Profesör Brand), Casey Affleck (Tom), Timothee Chalamet (Genç Tom), John Lithgow (Donald), Topher Greca (Getty), David Oyelowo ( Principal), Matt Damon (Dr. Mann), William Devane (Nasa Yetkilisi).

\section{Filmin Konusu ${ }^{3}$}

Yakın gelecekte Dünya gezegeni artık yaşanması zor bir yere dönüşmüştür. Küf adı verilen ve tarımı öldüren bir salgın sebebiyle kıtlık yaşanmaktadır. Iklim değişikliği sebebiyle de dünya eskisi kadar yağış almamakta sürekli toz fırtınaları oluşmaktadır. Hayatta kalmaya çalışan insan ırkı kıtlığı yenmek için yeniden tarım toplumu haline dönüşmüştür. Sadece 'mısır' üretimi yapılabilmektedir. Eskiden NASA test pilotu olan Cooper hayallerinden vazgeçip iki çocuğu ve kayınbabası ile mısır yetiştirmek zorundadır. Cooper'ın kızı Murphy odasındaki hayaletin ona bir şeyler anlatmaya çalıştığına kimseyi inandıramaz. Babası gibi bilime meraklı olduğundan hayaletin varlığını bilimsel yollarla kanıtlamaya çalışır. Öte yandan, halktan destek göremediği için çalışmalarını gizli yürüten NASA, Satürn gezegeni yakınlarında keşfettiği bir solucan deliği sayesinde Lazarus projesini bașlatır. NASA'nın gizli üssündeki Profesör John Brand'ın 'onlar' dediği uzaylı bir zekânın, Satürn yakınında bir solucan deliği açtığını, bir şekilde başka bir galaksiye geçerek yaşanabilir yeni bir gezegen bulunması için insanlığa bir umut verdiklerini söyler. NASA daha önce 12 gönüllü bilim insanını başka galaksilere yaşanabilir dünyalar aramak için göndermiştir. Astronotlardan gelen sinyaller sonucunda yaşanılır olması muhtemel üç (3) gezegen keşfi NASA'yı umutlandırır. Bu gezegenlere Miller, Edmund ve Mann isimleri verilmiştir. Gezegenler isimlerini keşif için oraya gönderilen astronotlardan almıştır. Cooper'ın pilotluğunu yaptığı Endurance uzay aracıyla beraberindeki astronotların görevi söz konusu gezegenlerdeki uzay istasyonlarından gelen veriye dayanarak hangi gezegenin insanlığın kurtuluşu için uygun olup olmadığını araştırmaktır. 


\title{
4.Propp’un 31 Karakter İșlevinin Interstellar'a Uygulanması
}

\author{
1.UZAKLAŞMA: Aileden biri evden uzaklaşır: Baba Cooper (kahraman) uzay \\ yolculuğuna çıkar.
}

2 ve 3. YASAKLAMA ve YASAĞI ÇiĞNEME: Kahraman bir yasakla karışlaşır: Cooper'ın ilk yasağı çiğnemesi NASA üssüne giriş şeklinde olur. Bu yasağın delinmesi (ihlali) anlatıyı başlatan en önemli unsurdur. Çünkü yasağın ihlali ile birlikte bir giz ortaya çıkmış; bu da yeni bir serüvenin ilk adımı olmuştur.

4 ve 5. SORUŞTURMA ve BILGi TOPLAMA: NASA'nın yaptığı gizli bir çalışma hakkında kahraman ve yardımcısı (Murphy) bilgi sahibi olurlar. Kahraman Cooper bilgiyi derinleştirir.

6.ALDATMA: Kahraman Cooper, olası bir uzay yolculuğunun insanlığı kurtaracağı konusunda gönderici tarafından yönlendirilir. Yolculuk hakkında ve elde edilecek zafer konusunda ikna olur ve fakat ilerleyen sekanslarda bunun doğru olamayacağını anlar. Yani, gönderici tarafından bir çeşit kandırılmayla (aldatılmayla) karşı karşıyadır.

7.SUÇA KATILMA: Kurban aldanır ve böylece istemeyerek düşmanına yardımcı olur: Kahraman Cooper'ın aldanması filmin ilerleyen sahnelerinde ortaya çıkar. Bu aldanış Dr.Mann'ın gezegeni hakkında gönderdiği doğru olmayan bilgilerdir.

8.KÖTÜLÜK ya da EKSIKLIK: Hain aileden birine zarar verir ya da aileden birinin eksiği vardır: Gönderici konumunda olan Profesör Brand (NASA yetkilisi), esasında Cooper'ı sonu olmayan bir göreve göndermesiyle bir ailenin zor durumda kalmasına neden olur. Özellikle küçük kız Murphy bu durumdan olumsuz etkilenir.

9.ARACILIK: Kötülüğün ya da eksikliğin haberi yayılır, bir dilek ya da buyrukla kahramana başvurulur, kahraman gönderilir ya da gider: Daha önceki maddelerde ifade edildiği gibi Cooper yeni yaşanabilir bir gezegen bulmak için gönderilir.

10.KARŞI EYLEMIN BAŞLANGICI: Arayıcı ya da kahraman eyleme geçmeyi kabul eder: Cooper uzaya gitmeyi kabul eder. Öte yandan filmin ilerleyen sahnelerinde karadeliğin etrafından dönen ve yaşam olasılığı bulunan bir gezegenin incelenmesi süreci de yeni bir eylemin başlangıcı olarak kabul edilebilir. Çünkü, bu gezegendeki yer çekimi dünyadaki zamandan farklıdır. Söz konusu gezegende bir (1) saat dünyadaki yedi (7) yıla karşılık gelmektedir. Kahraman Cooper ve diğer astronotlar burada tam üç (3) saat geçirirler. Gezegende meydana gelen dev tsunami dalgaları buradaki yaşamı imkânsız kılmaktadır. Bu başarısız keşif aynı zamanda dünyada geride bırakılan yakınlar için de bir yıkım oluşturmuştur. Kahramanın geri dönmesi konusunda ümitsizliğe düşmüşlerdir.

11.AYRILIŞ: Kahraman evden ayrılır: Cooper'ın evinden ya da Dünya'dan ayrılması ve belirsiz bir yolculuğa çıkması.

12.BAĞIŞÇININ İLK IŞLEVi: Kahraman büyülü bir nesne ya da yardımcı edinmesini sağlayan sınama, sorgulama, saldırı vb. gibi bir durumla karşılaşır: Büyülü nesne burada Cooper'ın kızı Murphy'e verdiği saattir. Murphy bu sekansta babasının gitmesini 
istemediği halde çerçeve öykünün gerektirdiği mecburiyet nedeniyle gidişi kabul etmek zorunda kalır. Böylece, anlatıda bağışçının ilk ve önemli işlevi ortaya çıkar.

13.KAHRAMANIN TEPKISi: Kahraman ileride kendisine bağışta bulanacak olanın eylemlerine tepki gösterir: Propp bu işlevde büyülü nesnenin değiş-tokuş edilmesinden söz eder. Filmde büyülü nesne saattir. Fakat Cooper, saat konusunda yardımcı görevinde bulunan kızıyla bir tartışma yaşar. Saati almak istemeyen Murphy, bu nesneyi kahramandan (Cooper) almazsa yolculuğun gerçekleşmeyeceğini ümit etmektir. Bu hareket eylemin gerçekleşmesini engelleyeceği için kahraman tarafından reddedilir. Propp (1987:71) bu konuda "kahraman objeleri değiştirmeyi kabul eder" derken, büyülü nesnenin hemen kullanıldığını da söyler. Fakat, burada nesnenin kullanımı hemen gerçekleşmez. Filmin düğümünün çözüldüğü sekansta gerçekleşir. Saatin büyüsü "esas düşman" doğayı alt ederken ortaya konulur.

14.BÜYÜLÜ NESNENIN ALINMASI: Büyülü nesne kahramana verilir: Yukarıda söz edildiği gibi anlatıdaki büyülü nesne saattir. Hem yardımcı (bağışçı) hem de kahraman büyülü nesne üzerinde anlaşırlar. Onu kullanma konusunda tartışırlar. Fakat, büyülü nesne araç olarak iki tanedir ve biri kahramanda diğeri de bağışçıda kalır. Çözümün gerçekleştiği sırada büyülü nesnenin gücünden bağışçı, kahramana yardım etmek için faydalanacaktır.

15.KILAVUZLUK: Kahraman aradığı nesnenin bulunduğu yere ulaştırılır, kendisine kılavuzluk edilir ya da götürülür: Kahraman Cooper, uzay gemisiyle yeni yaşam alanı olacak gezegenlere doğru yola çıkar. Burada uzay gemisi mürettebatı bilim insanları ve iki robot kahramana kılavuzluk etmektedir.

16.MÜCADELE: Kahraman ya da saldırgan bir çatışmada karşı karşıya gelir: Kahraman Cooper, yolculuk sırasında yaşam olasılığı bulunmayan bir gezegene iner, burada ölümle burun buruna gelir, fakat, sağ olarak kurtulmayı başarır. Bir diğer mücadele alanı ise Dr. Mann'la gerçekleştirilen çatışmadır. Bu sekansta Lazarus görevi nedeniyle daha önce gezegen aramak için gönderilen Dr. Mann ile kahraman Cooper karşı karşıya gelir. Çatışmada Dr. Mann yenilir. Kahraman yardımla çatışmadan zaferle çıkar.

17.DAMGALANMA: Kahraman özel bir işaret edinir (yaralanır, işaretlenir): Cooper yaralanır; ama, hayatta kalmayı başarır.

18.ZAFER: Hain yenik düşer: Dr. Mann yenik düşer ve ölür. Fakat, bu nihai bir zafer değildir. Büyük zafer insanlığın kurtuluşu ile gelecektir.

19.GIDERME: Başlangıçtaki kötülük giderilir ya da eksiklik karşılanır: Bu alt öykünün başlangıcındaki eksiklik giderilir. Fakat, burada büyük eksiklik giderilmez ve hala sorun çözülmüş değildir.

20.GERI DÖNÜŞ: Kahraman geri döner: Kahraman Cooper ve yardımcısı Dr. Amelia Brand uzay gemisine geri dönerler.

21.iZLEME/TAKIP: Kahraman izlenir: Bu alt-öykü kısmında kahraman Cooper'ın kurtarılmasına yardımcı olmak için Dr. Amelia Brand onu izlemektedir. 
22.YARDIM: Kahramanın yardımına koşulur: Cooper'a yardım edenler arasında TARS adı verilen zeki bir robot da vardır. Fakat, aslında masallardakine benzer yardımcı görevini (işlevini) yerine getiren uzay gemisinde birlikte yolculuk ettiği Dr. Amelia Brand'dır.

23.FARKEDILMEYEN VARIŞ: Kahraman kimliğini gizleyerek kendi ülkesine ya da bir başka ülkeye varır: Öykü yeni bir aşamaya geçer ve görevi başarmak için kahraman Cooper bilinmeyen bir ülkeye, filmdeki sahnede uzaya ve daha sonra da karadeliğe yönelir.

24.ASILSIZ SAVLAR: Düzmece bir kahraman asılsız savlar ileri sürer: Dr. Mann'ın kendi gezegeninde yaşamın imkânsız olduğunu bilmesine rağmen gerçeği gizleyerek yanlış bilgilerle diğerlerini yönlendirmesi ve kandırması asılsız savlardır.

25.GÜÇ GÖREV: Kahramana güç bir görev önerilir: Kahraman Cooper, içine girilmesi sonucunda ne olacağı kestirilemeyen karadeliğe girmeye karar verir ve karadeliğe girer. Öte yandan uzay yolculuğuna çıkmak da zaten başlı başına zor bir görevdir.

26.ÇÖZÜM: Görev yerine getirilir: Kahraman Cooper, teorik olarak zamanın durduğu varsayılan karadeliğe girişinde bir başka boyuta ya da çok boyutla bir mekânsızlık ortamına ulaşır. Bu ortamdaki nesnelerin hareket etme şekilleri tamamen farklıdır. Hatta, nesne ve madde kavramının yerini değişik biçimsiz şekiller almıştır. Buna rağmen Cooper, kızı Murphy’le iletişim kurmayı başarır. Bir şekilde kızının odasındaki kitaplıktaki kitapları 'hareket' ettirerek Morse alfabesiyle iletişim kurar ve insanlığın kurtuluşunu sağlar.

27.TANINMA: Kahraman tanınır: Cooper, karadelikten ve bu beş boyutlu sonsuz boşluktan nasıl olduğu belirsiz bir şeklide kurtulur ve gözlerini açtığında beyaza bezenmiş bir odadadır. Burada, onu tedavi edenlerden insanlığın kurtulduğunu öğrenip kendi adına inşa edildiğini sandığı 'Cooper istasyonunda' olduğuna anlar. Fakat, söz konusu istasyon esasında kızı Murphy’nin adına yapılmıştır. Yardımcıyla kahraman yer değiştirmiştir.

28.ORTAYA ÇIKARMA: Düzmece kahramanın ya da hainin kimliği ortaya çıkar: Bu kısımda ise ikili kahramanlık, yani, yardımcı ile gerçek kahraman arasındaki geçişliliğe şahit olunmaktadır. Murphy, insanlığı kurtaracak formülü çözdükten sonra gerçek kahraman statüsüne terfi ederken, birincil kahraman ve olay örgüsünün mimari baba Cooper ikincil konuma yani bir çeşit 'düzmece kahraman' durumuna düşer. Propp'un bu işlevinin filme uyarlanmasında sorunlar çıkmasına karşın kahraman ile yardımcısının öykünün ana sorununu çözmede yardımlaşırken anlatıdaki bu rol değişimi, çerçeve hikâyede zorunlu hale gelmektedir. Öte yandan, düzmece kahraman olarak ifade edilen Dr. Mann'ın keşfettiğini iddia ettiği yaşanabilir gezegenin bulunması gerçekleşmiş olsaydı yine anlatının ana kahramanı Cooper'la yer değiştirmesi zorunlu olacaktı. Anlatının olay örgüsü açısından kahraman, yardımcısı ve düzemece kahraman arasındaki geçişkenliğin ve rol değişimlerinin bu işlevde yoğun olarak gerekleştiğini kaydetmek gerekmektedir.

29.BiçiM DEĞişTiRME: Kahraman yeni bir görünüm kazanır; kahraman Cooper masallardaki ölümsüzlük iksirini yani ‘ab-ı hayat' suyunu içenler gibi genç kalmıştır. 
Yerçekimi kanunları nedeniyle zaman mefhumu (kavramı) anlamsızlaşmış ve kahraman Cooper yaşlanmamıştır. Öyle ki, kızı Murphy, onunla kıyaslandığında annesi yaşına gelmiş bir kadın görünümündedir. Kahraman değişime uğramamıştır. Hep genç kalmıştır. Bu durum masalın biçim bilimine uygun bir değişimdir.

30.CEZALANDIRMA: Hain cezalandırılır: Filmde hain işlevini yerine getiren Dr. Mann karakteri, filmin olay örgüsü ve diziminde erken bir aşamada ölümle cezalandırılır. Bu cezalandırma yine kahraman Cooper ve yardımcısı Dr. Amelia Brand'ın çabalarıyla gerçekleşir. Bir başka cezalandırılan karakter ise Cooper'ı dönüşü olmayan yolculuğa çıkaran ve onu ikna eden NASA yetkilisi Profesör Brand'dır. O, zamanın cezalandırmasına uğramış yani yaşlılıktan gözlerini hayata yummuştur.

31.BAŞARI: Kahraman evlenir ve tahta çıkar; senaryonun olay örgüsünde mutlu son ve başarıla tamamlanacak sahnesinde kahraman Cooper'ın, yolculukta kendisine yardımcı olan ve aralarında ilgiyle karışık sürtüşmelerin de varlığı hissedilen Dr. Amelia Brand'la kavuşması gerektiği ifade edilir. Bu dilek hasta yatağındaki yaşı Murphy'e söyletilir. Böylece kahraman ona kavuşmak için yola çıkar. Öte yandan Dr. Brand da yaşanılacak bir gezegen bulmuştur ve olası kahramanını beklemektedir. Bu son yeni bir başlangıç olarak kabul edilirse anlatılardaki 'denge' durumuna uygun yeni bir sürecin varlığı dikkati çekmektedir. Yeni bir denge durumu yaratılarak bir başka anlatının başlangıcı için ipuçları verilir (Todorov, 2014: 89).

\section{Filmdeki Kișilerin Eylem Alanları}

Saldırganın eylem alanı: Anlatıdaki açık saldırgan durumunda konumlandırılan Dr. Mann'dır. Kahramana Cooper'a karşı giriştiği mücadelede hem hile yapmış hem de onu öldürmeye teşebbüs etmiştir. Kahramanın yerine geçerek gerçekleşmesi gereken nihai zafere engel olmaya çalışmıştır.

Bağışçının eylem alanı: Filmde hem ikinci özne hem de bağışçılardan biri konumundaki Cooper'ın kızı Murphy'dir. Kahraman Cooper'ın, 5.boyuttaki bilinmez mekândan (mekânsızlık) kurtulmasını sağlaması, Morse alfabesinin şifrelendiği mesajı çözmesi ve uygun fizik denklemini bulması onu ikinci özne konumuna yerleştirmiştir. Filmdeki diğer bağışçı ve masal anlatılarına uygun konumunda bulunan kişi ise Profesör Brand'dır (Baba Brand). Kahramanın yolculuğa çıkmasını sağlayarak, ona güç bir görev vermiştir. Propp (1987:122), masallarda böylesi güç görevleri önermenin çoğunlukla babaya ait olduğuna dikkat çekmektedir.

Yardımcının ya da yardımcıların eylem alanı: Interstellar'da birden fazla yardımcı yer almaktadır. Bunlar kahramanın kızı Murphy, astronotlar; Dr. Amelia Brand, Romilly, Doyle ile robotlar; TARS ve CASE'tir. Murphy'le ilgili çözümlemelerin önemli bir kısmı yukarıda ifade edildiği için yardımcı eylem alanında bulunduğunu söylemek yeterlidir. Diğer yardımcıların olay örgüsündeki aksiyonları şu şekildedir:

Dr.Amelia Brand: Kahraman Cooper'ın filmin akışında zaman zaman tartışmaya girdiği fakat zor anlarda ona yardım eden bir karakteri temsil etmektedir. Bilim insanı olmanın verdiği 'bilgelikle' kahramana yol gösterirken, bazen bu aşırı kendine güven nedeniyle kahramanı zor duruma düşürmektedir. Örneğin, Dr.Edmund'un (Lazarus göreviyle gönderilen daha önceki keşif ekibinden biri) gezegene inip yaşamın 
olabileceği ısrarı ona aittir ve kahramanı bu eylemi yapmaya zorlar. Bu aksiyonun sonucunda hem kahramanın hem de mürettebatın hayatını tehlikeye atıp ölümle burun buruna gelmelerine neden olur. Yardımcı Dr. Amelia Brand bu süreçte yaralanır ve onu yine kahraman Cooper kurtarır. Fakat bu başarısız eylem sonrası, yardımcı tamamen kahramanın istekleri doğrultusunda hareket eder ve onu riskli olabilecek tüm eylemlerinde destekler. Örneğin kahramanın Gargantua karadeliğine girmesine engel olmaz (olamaz), artık tamamıyla kahramanın inisiyatifine terk edilmiş bir eylem alanı içindedir.

Romilly ve Doyle: Bu astronotlar kendi alanlarında uzman kişilerdir. İkisi de daha önce Lazarus görevine gönderilen öncü astronotlardan gelen sinyalleri değerlendirerek, uzay yolculuğunun amacına erişmesi için kahramanı yönlendirmektedirler. Özellikle Satürn çevresindeki galaksiler arası geçidin bir yolu olarak görülen 'solucan deliğine' girişte kahramana verdikleri bilgilerle geçidin geçilmesini sağlarlar. Fakat, her ikisi de olay örgüsü içinde zor koşullarla baş edemez ve hayatlarını kaybederler. Anlatıda olay örüntülerindeki kendi işlevlerine ve eylem alanlarına uygun düşen edimi yerine getirerek sahneden çekilirler.

TARS Ve CASE: Bunlar uzay seferinde tüm ekibe yardımcı olan teknolojik olarak süper gelişmiş yapay zekâya sahip robotlardır. Olağanüstü koşullarda gerek fiziki güçleri gerekse yüklendikleri bilgi donanımıyla kahramanın en büyük yardımcılarıdır. Adeta sihirli güçleri vardır. TARS, karadeliğe kahraman Cooper'la birlikte girer ya da düşer ve onu bu tanımlanması güç ortamda yönlendirir. Cooper'ın, kızı Murphy ile iletişim kurmasına da destek olur. Karadelikten kurtulduktan sonra TARS yine kahramanın yanındadır. Kahramanın belki de hayatta kalmasına sağlayan TARS' tır; fakat, bu hikâyede kesin olarak ifade edilmez.

Kahramanın eylem alanı: Kurmaca anlatının merkezindeki kişidir ve yaptığı tüm aksiyonlar hikâyenin gelişmesine ve sonuçlanmasına olanak verir. Filmin başından itibaren kahraman Cooper'da mevcut sisteme karşı bir tepkisellik ve karşı duruşu vardır. Kahraman dönemin idarecilerinin eğitim anlayışını, tarım politikalarını, uzay araştırmalarını eleştirir bir eylem alanı içerisindedir. Yani her an bu durumu değiştirmeye yönelik bir fırsat gözlediği hissettirilmektedir. Kahraman Cooper, kurmacanın başlangıçtaki denge durumunu bozmak için hazırlanmış bir karakter konumundadır. Gerek çocuklarının alacağı eğitim konusundaki tutumu, gerekse eğitimcilere-öğretmenlere dönük eleştirileri düzeni değiştirmeye yönelik aksiyonların içine gireceğinin ipuçlarını verir. Yani kahraman sıradan biri değildir ve sıradan olmayı reddetmektedir. Bu yüzden büyük işler yapmak için ona eylem alanı açmayı yine uğruna ölümü göze aldığı çocuklarından kızı Murphy sağlar. Murphy'nin 'iletişim' halinde olduğunu ileri sürdüğü 'hayaletleri' incelemek, kahramanın bir şekilde ilgi alanına sokulur ve başlangıç durumundaki denge hali dengesizlik lehine bozulur. Kahraman bundan sonraki tüm eylemlerinde olayların akışının ya içindedir ya da yönlendiricisidir: Uzay gemisinin idarecisidir ve solucan deliğine (beyaz delik) girip hayat intimali bulunan gezegenlere gitmek; ve, nihayet, çocuklarıyla iletişim kurmak için tek çarenin karadeliğe girmek olduğu gerçeğiyle yüzleşince bunları gerçekleştirmekten sakınmaz. Kahraman herkesten daha cesurdur ve bu ataklığı sayesinde hem çocuklarını hem de insanlığı kurtarır. Kahramanın eylem alanı masallardakine benzer bir şekilde tüm öyküye yayılmıştır. 


\section{Interstellar'ın Eyleyenler Modeline Göre Çözümlenmesi}

Propp'tan esinlenen Greimas'ın geliştirdiği 'eyleyensel örnekçenin' herhangi bir anlatıda şu üç şekilde gerçekleştiği belirtilir.

1) İletişim ekseni

2) İsteyim ekseni

3) Edim ekseni (Yücel, 2008:148).

Eyleyensel örnekçede şema ise:

Gönderici $\longrightarrow$ Nesne $\longrightarrow$ Alıcı (Illetişim ekseni)



Destekleyici $\longrightarrow$ Özne $\longleftarrow$ Engelleyici (Edim ekseni)

İletişim Ekseni; Gönderici - Nesne - Alıcı:

Söz konusu bağlam tüm iletim, aktarım ve alım olgularının gerçekleştiği düzlem olarak kabul edilmektedir. Bu eksende, göndericinin işlevi, başka bir kişi ya da nesneye; alıcıya bir şey iletmek ya da onun hangi nesneye gereksinimi olduğunu belirlemektir. Nesneyse, bu eksende göndericinin ilettiği ya da alıcının yoksun bulunduğu şey olarak tanımlanır (Yücel, 2008:148). Interstellar filminde ‘düğümün' çözülmesini de bu iletişim ekseni sağlar. Bu düzlem filme uyarlandığında şu şekil ortaya çıkmaktadır.

İletişim Ekseni:

Gönderici(Baba Cooper) — Nesne (Saat-Morse alfabesi kodlu) Alıcı: $\rightarrow$ Murphy (Cooper'ın kızı)

İsteyim Ekseni: (Özne-Nesne)

Burada özne, iletimin kaynağı kendisi olmamakla birlikte, gerçekleştirdiği değişik eylemlerle önündeki tüm engelleri aşarak nesnenin alıcıya ulaşmasını sağlar. Bunun gerçekleşmesi için onun iletime karışması zorunludur (Yücel, 2008:148). Interstellar filminde Cooper, kızına istediği bilgiyi ulaştırmak için Morse alfabesi kodlu saat üzerinden bir iletim gerçekleştirmek isterken kendisine yardımcı olan TARS adı verilen robottan yardım alır, zaman ve boyut farklılığını aşar. Bu isteyim ve süreç şu şekilde gerçekleşmektedir:

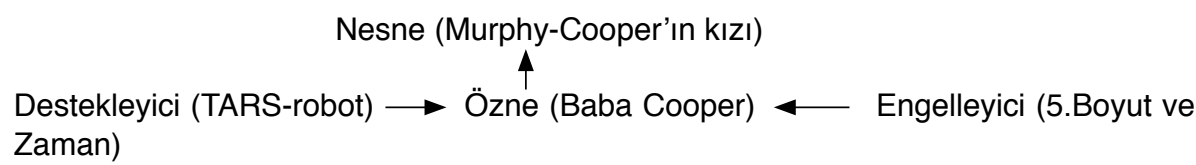

Edim Ekseni: (Destekleyici-Özne-Engelleyici) 
Bu eksen; destekleyici-özne-engelleyici olarak ifade edilmektedir. Öznenin isteyimden gerçekleştirime geçtiği, yani eylemin gerçekleştirmek için gerekli güçle donandığı düzlemdir. Bu gücü, kendisine kimi kez bir kişi, kimi kez bir nesne, kimi kez bir nitelik, kimi kez bir bilgi olarak tanımlanan ya da bunların hepsini birden içeren destekleyici sağlar. Engelleyici aynı zamanda bir kişi, bir nitelik, bir bilgi olabilir ya da bunların hepsini birden içerebilir.

Destekleyici (Morse alfabesi kodlu saat) $\longrightarrow$ Özne (Baba Cooper) $\longleftarrow$ Engelleyici (5.Boyut-zaman)

\section{Interstellar' in Anlam Kesitleri:}

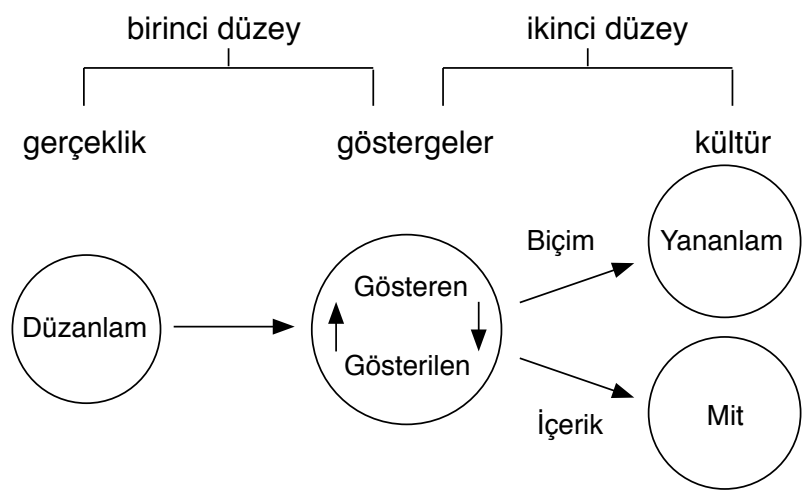

Şekil.1 Roland Barthes'ın iki anlamlandırma düzeyi. Birincinin gösterge sistemi, ikinci düzeyde kültürün değer sistemi içine yerleştirilmiştir (Fiske, 2003:120).

John Fiske (2003:120), anlamlandırmanın birinci düzeyi olarak, göstergenin göstereni ve gösterilen arasındaki ilişkiyi ve göstergenin dışsal gerçeklikteki göndergesiyle ilişkisini betimlediğini, Barthes'ın bu düzeyi 'düz anlam' olarak ifade ettiğini belirtmektedir. Düz anlam, göstergenin ortak duyusal, aşikâr anlamına gönderme yapmaktadır. Göstergelerin ikinci düzeyde işleyişine ilişkin olarak da yine Barthes'ın üç yoldan ikincisi olduğunu belirttiği 'mit' aracılığıyla gerçekleştirilendir. Fakat, Barthes'ın 'mit' konusundaki yaklaşımı Claude Lévi-Strauss'tan farklıdır, bunlar daha çok ideolojik temellidir. Efsanelerden ayrılmaktadırlar. Mit; bir kültürün, gerçekliğin ya da doğanın bazı görünümlerini açıklamasını ya da anlamasını sağlayan bir öyküdür. İlkel mitler, yaşam ve ölüm, insan ve tanrılar, iyi ve kötü hakkındadır (Fiske, 2003:118). Barthes, kültürel ve edebi eleştirilerinde yan-anlam kavramını, metinlerde gizli olan anlamı tespit etmek için kullanır. Mitler çalışmasında, ikincil anlam sistemini mitler olarak tanımlamaktadır. Yan anlam, göstergenin kullanıcıların duygularıyla, heyecanlarıyla, kültürel değerleriyle birleştiğinde ortaya çıkan etkileşimi belirtir. Burada, anlam öznelliğe doğru kayar; çünkü, yorum yorumlayıcıdan olduğu kadar nesne veya göstergeden de etkilenir. Yananlamsal göstergelerin çözümlenebilmeleri için, üretildikleri toplumsal yapıya ait özelliklerin de bilinmesi gerekmektedir. Bu bağlamda, göstergelerin yorumlanmasında rüya ve mit arasında bir anoloji kurmak mümkündür. Freud'un geliştirdiği yöntemle rüya ve kültür arasında bir ilişki olduğu kaydedilmektedir. Nasıl rüyayı gören kişi, onun yüzeysel anlamına odaklanacak ve daha derin gerçek anlamını 
bilemeyecekse mitlerin de rüyalar gibi çözümlemelere tabi tutulması gerekmektedir. Mitler, rüyalar gibi insanların kültürel bilinçaltlarında gizlenen bastırılmış endişelerden ve çözümsüz çelişkilerden kaynaklanmaktadır. Mitler yapısalcı çözümlemelerle analiz edilmektedir; çünkü ilgi odağı bireye özgü anlamlar değil, kültüre özgü anlamlardır (Fiske, 2003:160).

\section{Interstellar'daki Göstergelerin Çözümlenmesi}

Mısır Bitkisi: Interstellar filminin derin anlamlarından biri Kuzey Amerika yerlilerinin (Penobscot yerlileri) Corn Mother (Mısır Anne) mitolojisinde yatmaktadır. Mitolojide çocuklarını açlıktan ölmekten kurtarmak için kendini feda eden mısır annenin fedakârlığı anlatııır. Yerlilerin mitolojisine göre, tüm insanlığın ilk annesi mısırdır ve insanlığı açlıktan ölmekten mısır kurtarmıştı ${ }^{4}$. Maya, Aztek ve diğer yerli Amerikalıların da mısır tanrılara taptıkları bilinmektedir. Mısır tanrı ve tanrıçaların çoğunluğu kadın ve bereketle ilişkilidir ${ }^{5}$. Filmde, bu mitolojik unsur tüm dünyada yok olma noktasına gelen hayatın kurtarıcısı ve insanlığı besleyici durumda kalan tek bitkinin mısır olmasıyla vurgulanmıştır. Filmde mısır bitkisi mitolojideki 'mısır anneyle' bir çeşit özdeşlik kurulmasını sağlamaktadır. Yaşlı Murphy'nin ölüm döşeğindeyken aile bireyleriyle buluşması tüm insanlığın bir araya gelmesine yapılan bir gönderme olarak değerlendirilebilir.

\section{Mısır Tarlası Sekansları:}

\begin{tabular}{|lll}
\hline Gösterge & Gösteren & Gösterilen \\
\hline Doğa & Mısır & Açlık ve tokluk \\
\hline Toprak & İnsan & $\begin{array}{l}\text { Verimsizlik, çaresizlik ve olası büyük } \\
\text { felaket. }\end{array}$ \\
\hline İnsan & Kadın & $\begin{array}{l}\text { Mitolojideki mısır anne figürüne } \\
\text { gönderme yapılmakta. }\end{array}$ \\
\hline
\end{tabular}

\section{Karşıtlıklar}

\begin{tabular}{|ll|}
\hline Fedakârlık & Bencillik \\
\hline Açlık & Tokluk \\
\hline Sağlık & Hastalık \\
\hline Tanrı & Tanrıça \\
\hline Ölüm & Yașam \\
\hline
\end{tabular}

$4 \mathrm{http}: / /$ hayrabolutb.org.tr/media/ziraat/Misir-Tarimi-2.pdf

5 http://www.mythencyclopedia.com/Ca-Cr/Corn.html 


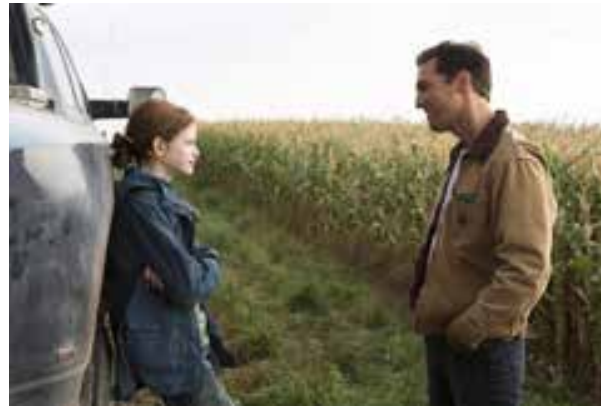

Görsel-1, Murphy ve Babası Cooper.

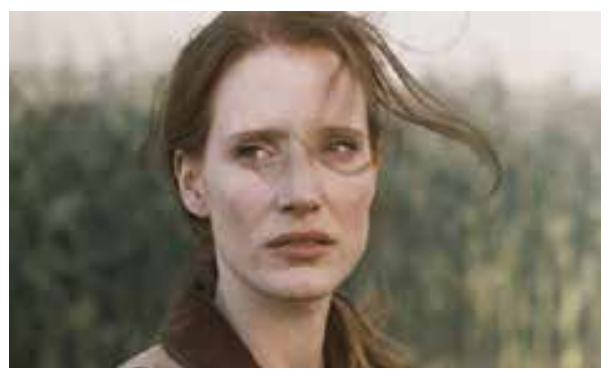

Görsel-3, Murphy ve mısır püskülü saçları.

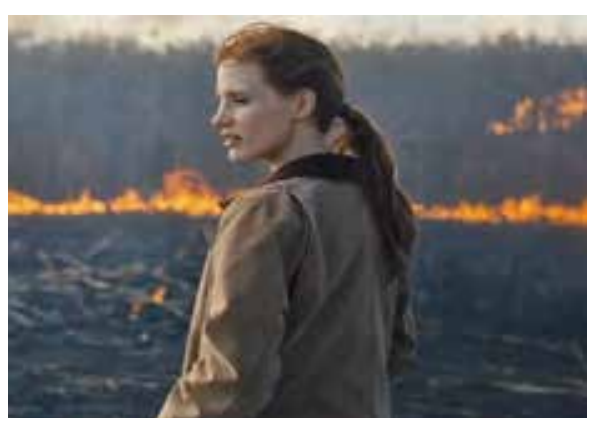

Görsel-2, Murphy mısır tarlasını yakıyor.

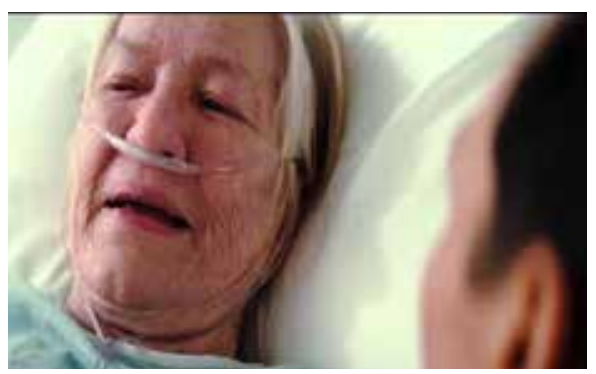

Görsel-4, Yaşlı Murphy ölüm döşeğinde.

Murphy Kanunları: Cooper'ın kızının filmdeki ismi Murphy'dir. Dünyanın birçok ülkesinde Murphy kanunları genelde günlük hayatta işlerin ters gideceği çağrışımıyla tanınmaktadır. Esasında söz konusu kanunlar, olması muhtemel şeylerin mutlaka olacağını ifade eder. Kanunlar, filmde gösteren-gösterilen ilişkisi içinde verilmiştir; genç kız Murphy gösteren, Murphy kanunları ise gösterilen durumundadır. Filmde, Murphy kanunlarına referans verilmesi izleyiciyi olacak olumsuzluklara ya da muhtemel sonuçların bu kanunlar çerçevesinde şekilleneceğine yönelik bir hazırlıkla yakından ilgilidir. Bu noktada ismin gerçek anlamının ötesinde çağrışımsal yan anlamlar oluşturulmuştur. Filmin diğer kodlamalarında olduğu gibi Murphy ismi, olay örgüsünü şekillendirmek ve öykü anlatımının özelliklerinin sinema izleyicisi üzerinde etki yapacağı varsayılarak seçilmiştir. Bu amaçlı seçime filmde genç Murphy ile babası Cooper arasında geçen bir diyalogla izleyici ortak edilir. Genç kız, babasına, isminin neden olumsuzlukları çağrıştıran Murphy ismi konulduğunu sorduğunda doyurucu bir yanıt alamaz. Murphy kodlamasıyla, filmdeki tüm olumsuz süreçlerin birbirini izleyeceğine dikkat çekilerek, seyirci hazır hale getirilmiştir. 


\section{Murphy Kanunları Sekansı:}

\begin{tabular}{lll} 
Gösterge & Gösteren & Gösterilen \\
\hline İnsan & Cocuk & $\begin{array}{l}\text { Olumsuzluk duygular ve buna bağlı olarak ișlerin ters } \\
\text { gideceği endișesi. }\end{array}$ \\
\hline Konu & Nesne & $\begin{array}{l}\text { Kendiliğinden çalıșan traktörler ve kitapların hareket } \\
\text { etmesi. }\end{array}$ \\
\hline Doğa & Toz & Felaketin habercisi hayaletin varlığı duygusu. \\
\hline
\end{tabular}

\section{Karşıtlıklar}

\begin{tabular}{|ll}
\hline Kötümserlik & İyimserlik \\
\hline Gerçeklik & Hayal \\
\hline İyi & Kötü \\
\hline Felaket & Refah \\
\hline
\end{tabular}
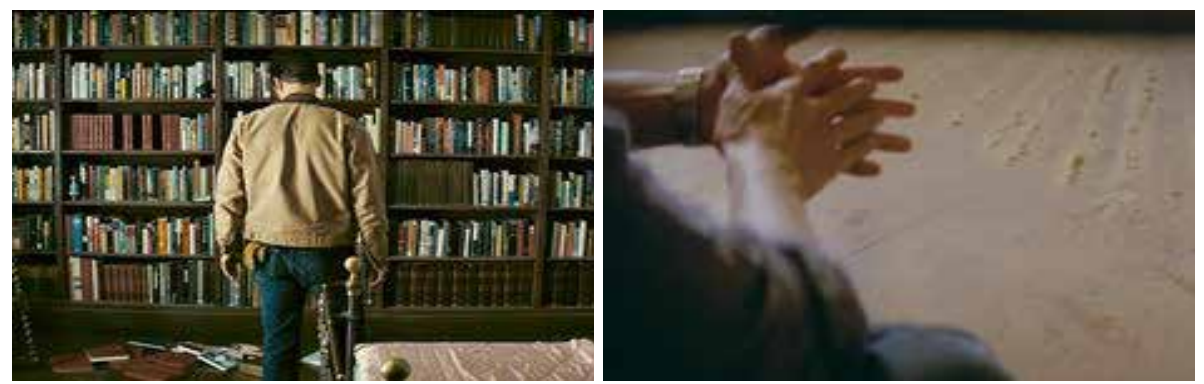

Görsel-5, Kitaplıktaki hayalet sahnesi.

Görsel-6, Hayalet sanılan yerçekimi sahnesi ve toz.

Lazarus Görevi: İnsanlığı kurtarmak ve yaşanabilir gezegenler bulabilmek için uzaya gönderilen astronotların görev seferine verilen isimdir. Filmdeki çağrıştırdığı anlamı Lazarus olayı ya da olgusu Hıristiyan mitolojisinde ve İncil'de geçen Hz. İsa'nın ölü bir insanı diriltmesine yapılan göndermedir 6 . Kutsal mitolojiye yapılan bu göndermede filmin evrensel kodlamalarından birini oluşturmaktadır. Hıristiyanlığın gelecek yüzyıllarda da varlığını koruyacağına atıfta bulunurken, bu dine inanan insanlar için de garanti vermektedir. Propp (1995:206-207), bir toplumun yaşayan dini ile masal karşılaştırıldığında olayın tümüyle farklı olduğunu; örneğin, Hıristiyanlığa ilişkin öğelerin masaldan önce değil masaldan sonra ortaya çıktığını ifade eder. Olağanüstü masalların eski dinlerden geldiğini ama çağdaş dinin masallarından gelmediğini; çağdaş dinin, masalların yaratıcısı olmadığını yalnız onların öğelerini değişikliğe uğrattığını kaydeder. Yine de din öğelerinin masallardan geldiği durumların da bulunduğuna dikkat çeker. 


\section{Lazarus Görevi Sekansları:}

\begin{tabular}{lll} 
Gösterge & Gösteren & Gösterilen \\
\hline İnanç & İnsan & Dini inaçların insanda her zaman var olacağı. \\
\hline Kültuir & İnsan & Hıristiyan inancının evrenselliği teması. \\
\hline Konu & Bilim & $\begin{array}{l}\text { Dinin vaaz ettiği emirleri bilimin yerine getirebileceği } \\
\text { fikri. }\end{array}$ \\
\hline
\end{tabular}

\section{Karşıtlıklar}

\begin{tabular}{|ll} 
Ölüm & Yașam \\
\hline Gençlik & Yașlılık \\
\hline Din & Bilim \\
\hline
\end{tabular}
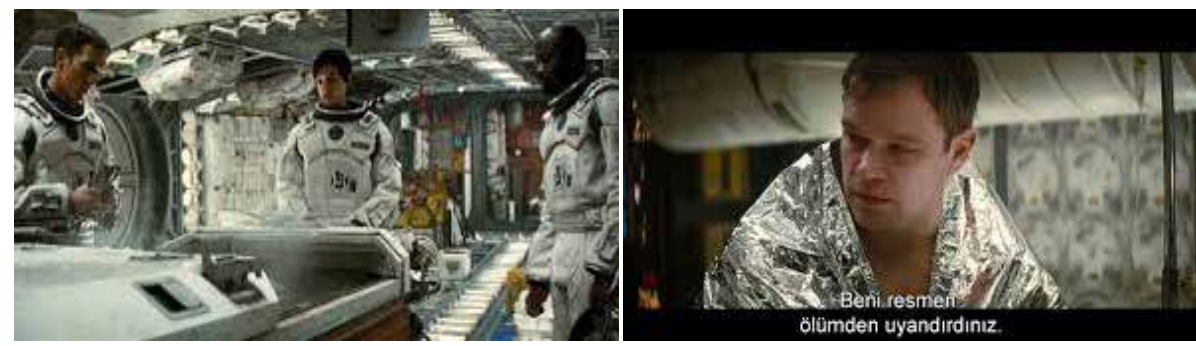

Görsel-7 ve Görsel-8; Lazarus görevindeki astronot Dr. Mann'ın derin uykudan uyandırıldığı sahne.

Gargantua Karadeliği: Gargantua ismi, 16. yüzyılın önemli hümanistlerinden Fransız yazar François Rabelais'ın baba ile oğlunun hikâyelerini anlattığı fantastik edebi bir eserden gelmektedir. Fantezi, güldürü ve felsefi nitelikler taşıyan bu eserde dönemin eğitim sistemi acımasız ve aynı zamanda eğlenceli bir şekilde eleştirilir. Rabelais'ın eserindeki devler Gargantua ve onun oğlu olarak karakterize edilen Pantagruel, sürekli yemek yiyen ve bir türlü doymak bilmeyen niteliğe sahiptirler. Yazarın söz konusu eserde dönemin eğitim sistemi ile birlikte toplumsal yapısını da eleştirmesi onun Rönesans'ın habercisi olarak sayılmasına neden olmuştur ${ }^{7}$. Filmin birçok noktasındaki bilimsel önermeye denk düşmekle birlikte, uzay boşluğunda hemen her şeyi yutan karadeliğe Gargantua isminin verilmesi tesadüf değildir. Önemli kültürel kodlamalardan birini oluşturur. Bir yandan Gargantua karadeliği dev ve doymak bilmez biriyle özdeşleştirilirken diğer yandan insanlığın yeni Rönesans'ının ancak galaksiler aracılığıyla gerçekleştirilecek yolculuktan geçtiği mesajı kodlanmaktadır. Ayrıca bu sekansta bir başka dikkati çeken nokta ise zamanın insanlar üzerinde yaptığı etkidir. Bu etki astronot Romilly'nin sakallarının beyazlaması görseliyle anlatılmıştır. 


\section{Gargantua Karadeliği Sekansı:}

\begin{tabular}{|c|c|c|}
\hline Gösterge & Gösteren & Gösterilen \\
\hline Doğa & Uzay & Sonsuzlukta yok oluș \\
\hline Karadelik & İnsan & $\begin{array}{l}\text { İnsanlı̆ın varlık ya da yokluk arasında yapmak zorunda } \\
\text { olduğu tercih }\end{array}$ \\
\hline Bilim & Robotlar & $\begin{array}{l}\text { İnsanlığın yeni dünyaları keșfetmesinde teknolojinin ve } \\
\text { bilimin zorunlu olduğu gerçeği. En büyük yardımcılar } \\
\text { da robotlar. }\end{array}$ \\
\hline Nesne & Kitaplar & Bilginin kitaplar yoluyla öğrenilebileceği \\
\hline
\end{tabular}

\section{Karşıtlıklar}

\begin{tabular}{|ll}
\hline Ölüm & Yașam \\
\hline Gençlik & Yașlılık \\
\hline Ümit & Ümitsizlik \\
\hline Yok oluș & Kurtulus \\
\hline Bilim & Din \\
\hline Eğitim & Cahillik \\
\hline
\end{tabular}
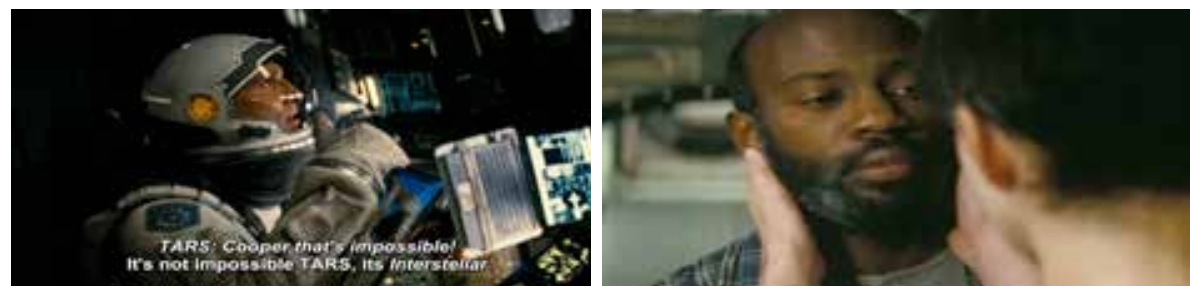

Görsel-9, Cooper 5.boyutta imkânsızı başarıyor. Görsel-10, Astronot Romilly'nin sakallarının beyazladığı sahne.

Dusty Bowl (Toz Fırtınası): 1934-1937 yılları arası ABD'de meydana gelen şiddetli kuraklık sırasında toz bulutlarının tarımı felç ettiği dönem olarak bilinir. Bu yüzden 1930'lara 'The Dust Bowl' yani toz fırtınası dönemi adı verilmiştir. Söz konusu dönem, aynı zamanda Amerikan ekonomisinin çöktüğü, bunun etkilerinin tüm dünyada hissedildiği ve insanların açlıkla boğuştuğu büyük bir sosyo-ekonomik felaket olarak hatırlanmaktadır. Amerika'da felaketi yaşayan insanlar büyük sıkıntılar çekmiş ve bu süreç yaklaşık on yıl sürmüştür. Tarımdaki bu yıkımın olumuz etkileri dünya çapında hissedilmiştir8. Dönem, Amerikalı yazar John Steinbeck'in 1939'da kaleme aldığı 'Gazap Üzümleri' romanıyla da insanlığın hafızasını yazılmıştır. Söz konusu 'toz fırtınasına' filmde önemli bir yer ayrılmış, bellekte diri ve hala korku yaratıyor olması onu mitolojik bir unsura dönüştürmüştür. Interstellar'ın da anlam kesitlerinden birini oluşturmuştur. 
Toz Bulutu (Dusty Bowl) Sekansı:

\begin{tabular}{|lll|}
\hline $\begin{array}{l}\text { Gösterge } \\
\text { Doğa }\end{array}$ & Gösteren & Gösterilen \\
\hline Nesne & Aozăanın insanlara karșı ıçok acımasız & $\begin{array}{l}\text { olabileceği düșüncesi. } \\
\text { Modern araçların gün gelip doğanın } \\
\text { egemenliğine boyun eğeceği. }\end{array}$ \\
\hline İnsan & Toprak & $\begin{array}{l}\text { Amerika'da 1930'lu yıllarda tarımda yașanan } \\
\text { büyük depresyona yapılan gönderme. }\end{array}$ \\
\hline
\end{tabular}

\section{Karşıtlıklar}

\begin{tabular}{|ll} 
Doğa & İnsan \\
\hline Kıtlık & Bereket \\
\hline Acı & Mutluluk \\
\hline Geçmiș & Gelecek \\
\hline Kriz & İstikrar \\
\hline Felaket & Kurtuluș \\
\hline
\end{tabular}
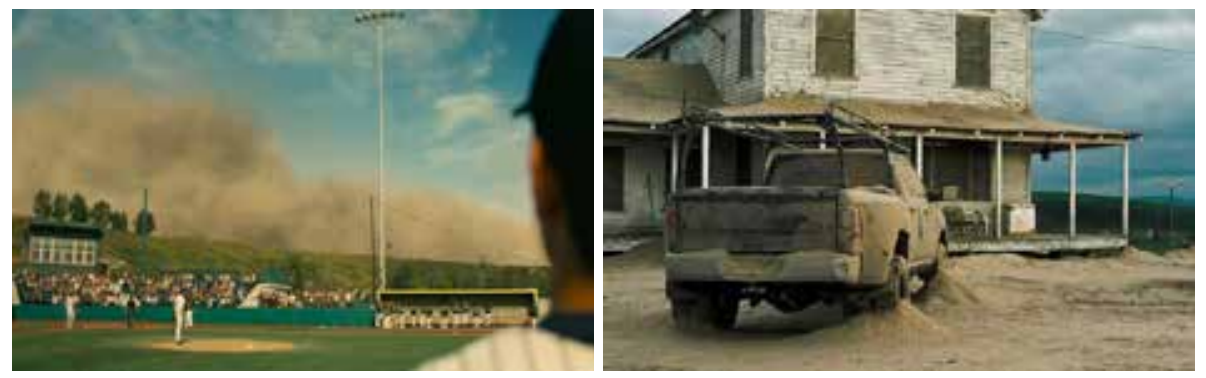

Görsel-11 Görsel-12 Toz bulutu, beyzbol maçı ve toz fırtınası sonrası Cooperların evi.

Morse Alfabesi: Neil Postman (2004: 78), Morse'un bulduğu yöntem ve dil sayesinde elektriği iletişimin hizmetine sunduğunu, hatta, onun Amerika'nın ilk 'uzay adamı' sıfatını hak ettiğini belirtmektedir. Morse alfabesi ve onun kullanım alanı olan telgraf coğrafi tüm engelleri aşacak bir tekniği insanlığın hizmetine sunarken, mesafeleri ortadan kaldırmış, keşifler, savaşlar ve gazete haberleri yeni icatla birleşen kodlama sistemiyle bambaşka bir boyuta taşınmıştır. Söz konusu iletişim aracı telgraf sayesinde tüm ülkenin tek bir mahalle haline geldiği ifade edilirken (Postman, 2004:78), Morse'un uzay araştırmalarıyla ilişkilendirilmesi ise 'bilim-kurgu' filmine konu oluvermiştir. Morse alfabesi nasıl Amerika'yı ve dünyayı coğrafi olarak tek bir bütün altında topladıysa, filmde de evrenler arasındaki iletişimi sağlamak da ona havale edilmiştir. 
Morse Alfabesiyle İIgili Sekans:

\begin{tabular}{|lll}
\hline $\begin{array}{l}\text { Gösterge } \\
\text { Saat }\end{array}$ & $\begin{array}{l}\text { Gösteren } \\
\text { İnsan }\end{array}$ & $\begin{array}{l}\text { Gösterilen } \\
\text { Morse alfabesinin zamanı ve sınırları aștığı, } \\
\text { insanların hayatlarını değiștirdiği. }\end{array}$ \\
\hline Hayalet (hurafe) & Çocuk & $\begin{array}{l}\text { İnsanların boș inançlar saydığı bazı olağanüstü } \\
\text { șeylerin var olabileceği. }\end{array}$ \\
\hline İletișim & Morse alfabesi & $\begin{array}{l}\text { İnsanlar arasında temel sorunun iletișimsizlik } \\
\text { olduğu. }\end{array}$ \\
\hline Yazı & İnsan & Morse alfabesiyle duyguların ifade edilmesi. \\
\hline
\end{tabular}

\section{Karşıtlıklar}

\begin{tabular}{|ll}
\hline Bilim & Hurafe \\
\hline İletișim & İletișimsizlik \\
\hline Hız & Yavașlık \\
\hline Modernlik & İlkellik \\
\hline Cocukluk & Yetișkinlik \\
\hline
\end{tabular}
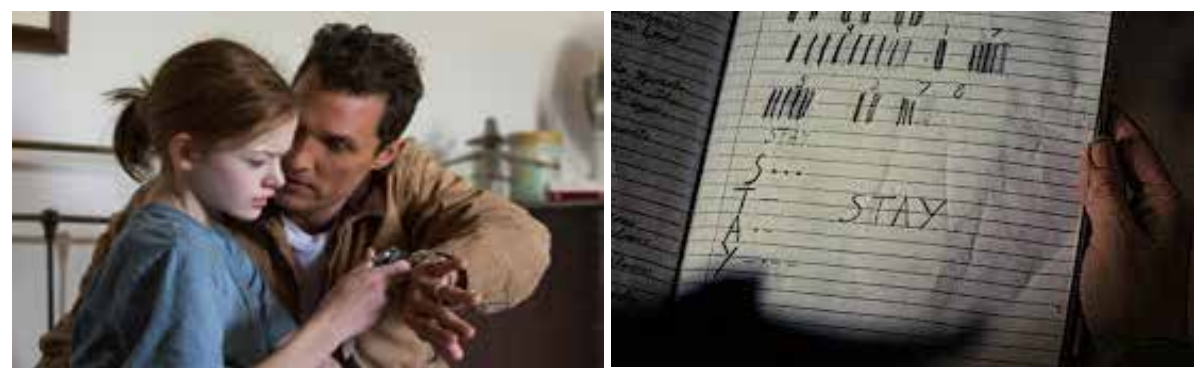

Görsel-13 ve Görsel-14, Murphy ve Cooper'ın saatlerini ayarladığı ve Morse alfabesiyle kurulan iletişim sekansları.

Satürn gezegeni ve yakınındaki solucan deliği: Filmde, Satürn gezegeninin diğer uzay cisimlerine tercih edilmesi, mitolojik unsurlara gönderme yapılarak yananlam oluşturma işlevi nedeniyledir. Satürn, Roma mitolojisinde 'zaman tanrısı' ve titan kralı yani 'Titan Tanrı' olarak bilinir. Yunan mitolojisinde Kronos'un dengidir. İlk titan olmakla birlikte, zamanı yarattığı ve zamanlarda seyahat ettiği söylenir.(https://tr.wikipedia. org/wiki/Kronos,11.09. 2015). Geri dönüşü olmayan bir yola benzetilen Satürn, çevresindeki solucan deliği zamanı sembolleştirerek somutlaştırmış, bu vesileyle mitolojik tanrıya gönderme yaparak insanlığın zaman tanrısı tarafından yok edileceği teması işlenmiştir. 


\section{Satürn Gezegeni ve Solucan Deliği Sekansı:}

\begin{tabular}{lll} 
Gösterge & Gösteren & Gösterilen \\
\hline Doğa & Gezegen & Paganlık döneminden kalan mitolojik inançlar. \\
\hline İnsan & Zaman & $\begin{array}{l}\text { Zaman tanrısı Satürn'e yapılan göndermede } \\
\text { insanların sadece zaman karșısında çaresiz kalacağı } \\
\text { vurgulanmıștır. }\end{array}$ \\
\hline Konu & Doğa & $\begin{array}{l}\text { Bilim çağında bile insanların dini inançlarının kuvvetli } \\
\text { olacağı gerçeği. }\end{array}$ \\
\hline
\end{tabular}

\section{Karşıtlıklar}

\begin{tabular}{|cl|}
\hline Tek Tanrı & Paganlık \\
\hline Bilim & Din \\
\hline Mitoloji & Gerçeklik \\
\hline
\end{tabular}
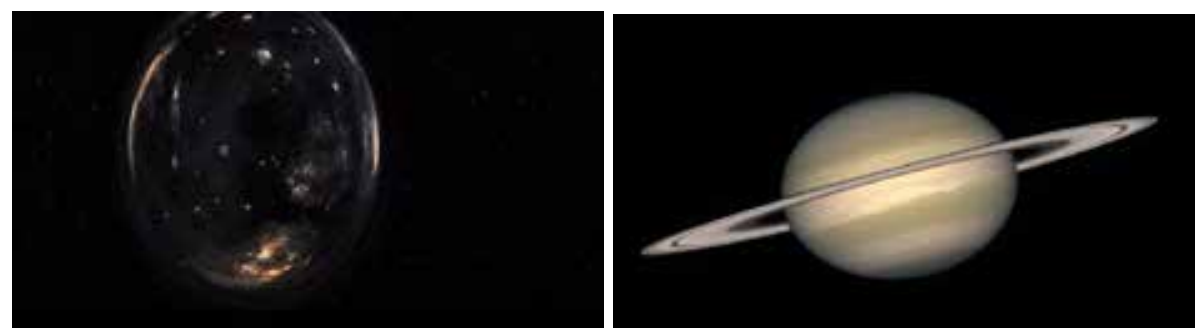

Görsel-15, Filmdeki solucan deliği imgesi.

Görsel-16, Gerçek Satürn gezegeni resmi.
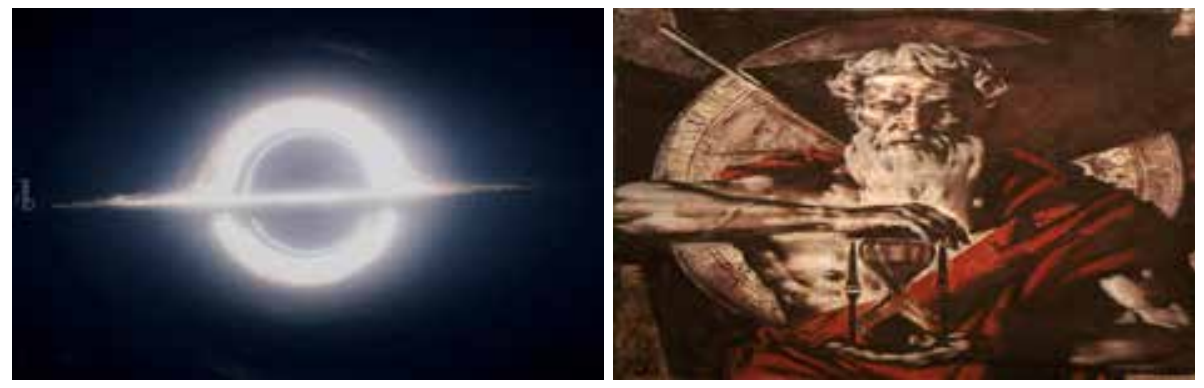

Görsel-17, Filmdeki karadelik imgesi.

Görsel-18, Mitolojideki zaman tanrısı Satürn.

\section{Bulgular ve Tartıșma}

Yapılan çalışmada, çağdaş bilim-kurgu filmi olan 'Interstellar'ın olay örgüsündeki anlatım özellikleri ve olayların gelişiminin V.Propp'un olağanüstü peri masalları izlencesindeki 'işlevleriyle' örtüştüğü görülmüştür. Bu durum, anlatıların yapısal 
özelliklerinin, anlatıcılardan ve yazarlardan bağımsız olabileceği şeklindeki 'yapısalcı' tezi doğrulamaktadır. Film sözlü ve yazılı mitolojilere gönderme yaparken masalsı; fizik biliminin astro-fizik alanına ilişkin bilgiler verirken bilim-kurgusal anlatı özelliklerine sahiptir. Senaryo mitsel ve ideolojik anlamlar çerçevesinde bir işlev görmektedir. İzleyicide doyum ve haz sağlamak için hikâyedeki tüm sorunların çözümü yoluna gidilmiştir. Propp'un masal anlatısı izlencesi ve bu formun temel unsurları ağırlık olarak hissedilirken, filmin senaryosunda Tzvetan Todorov'un (2014:89), 'ideal anlatı' olarak sözünü ettiği, sabit bir durumla başlayıp sonra dengenin bozulması, nihayetinde yeni bir dengenin kurulmasıyla süren olay örgüsü yapısının varlığı da tespit edilmiştir. Kahramanın insanlığı kurtarması ve filmde 'mutlu sonun' gerçekleşmesi klasik anlatılardaki 'katarsisin' varlığını da ortaya koymaktadır. Böylece, Aristo'nun tragedyalardaki gerilim, ardından yaratılan rahatlama ve olumlu hesaplaşma dediği finalin gerçekleşmesi sağlanmıştır (Bloom, 2012:213).

Mevcut dünya sisteminin güncel resmi ideolojisi bilimin, batı merkezli olabileceği tezi yeniden üretilirken, onun da sınırlı olabileceği ve insanların zor durumlarda bilimdışı olgular ve öznelerden yardım alabileceği 'fantezisi' işlenmiştir. Amerikan toplumundaki temel değerlerin önemi vurgulanmakta, orta sınıf Amerikan ailesi referans alınarak toplumsal bir zemine oturtulmaktadır. Tarım toplumuna dönüldüğü kaydedilse de teknolojinin yine başat unsur olduğu dikkati çekmektedir; insansız hava araçları, yapay zekâyla çalışan tarım makineleri hala varlıklarını korumaktadırlar. Bu da doğanın yine teknolojiyle ehlileştirileceği tezine uygun bir argümana denk düşmektedir. Doğa, toprak, uzay yani insan dışı varlıklar düşmanlaştırılmış, ancak, olağanüstü varlıklar 'dost' olarak lanse edilmiştir. Bilimin çaresiz kaldığı anlarda 'doğaüstü' varlıklar sorunun çözümüne yardımcı olmaktadır. Kahraman Cooper'ın karadelikten kurtuluşu ile Satürn yakınlarında solucan deliğini açanlar bu olağanüstü varlıklardır. Bu bakımdan filmde 'dinsellik' vurgusu tercih edilerek, ortalama izleyiciyi tatmin etme yolu seçilmiştir.

Hıristiyanlıkla ilgili motifler senaryoda yer almaktadır. Bu da filmin hedef kitlesinin tatminine yönelik bir gayretin olduğunu göstermektedir. Filmin güncel anlamdaki 'mitsel' ve 'ideolojik' bir metin olarak yorumlanmasında ise karşımıza bildik Amerikan söylemi ve ataerkil iktidar biçimlerinin yeniden üretilmesi çıkmaktadır. Bu yaklaşımda, Todorov'un metin okuma biçimlerinden hareket edilmesi gerekmektedir. Tzvetan Todorov (2014:80-81), yapısalcılarda metinlerin iki türlü okuma (çözümleme) yönetimine dikkat çeker; bunlardan biri 'mitolojik' diğeri ise 'ideolojiktir'. Mitolojik anlatıda öykü açısından gerekli olan belli belirsiz bir kavrama göndermede bulunulurken, karakterlerin kişilik özellikleri, kimlikleri ve ortama dair bilgiler ortaya konulur. İdeolojik anlatıda ise kendisini oluşturan birimler arasında doğrudan bir bağlantı kurulmaz, ancak, bu birimler bizim gözümüze tek bir düşüncenin, tek bir yasanın dışavurumları gibi görünürler. Eşvaroluşları tamamen olumsal gibi duran iki eylemin arasındaki ilişkiyi bulmak için kimi zaman soyutlamayı epeyce ileri götürmek gerekir. İdeolojik anlatıda elde olmayanın arzulandığı ve elde olandan kaçınıldığı ve sonuç olarak da her engelin arzuyu güçlendirdiğine vurgu yapılır. Filmdeki bu mitsel ve ideolojik unsurlar şu şekilde ifade edilebilir. Karar alıcıların ve keşfe çıkanın 'erkek' ve yardımcının 'kadın' olması, mevcut toplumsal yapının yeniden üretimini sağlamaktadır. İnsanlığı kurtaracak fizik formülünün üzerinde her ne kadar kadınlar (Murphy) çalışsa da sorunun kahramanın (Cooper) çabalarıyla çözüldüğü gerçeği dikkatlerden kaçmamaktadır. Olay örgüsünde, masallarda olduğu gibi, filmde de evden ayrılanın 'erkek'(çoğunlukla) figürünün olmasıyla dünyayı veya ülkeyi kurtaracak olanların da 'erkekte-babada' somutlaşması 
patriarkal merkezli egemen bir bakışın ürünüdür. Güncel mitlerden biri de Dünya'yı ve insanlığı kurtaracak olanların Amerikalılar tezinin işlenmesidir. Filmin ideolojik göstergelerinden biri de özellikle soğuk savaş döneminden kalan Ay'a yolculukların gerçekleşmediği yönündeki tartışmalara da gönderme yaparak NASA'dan yana tavır alınmasıdır. Bununla bağlantılı olarak Interstellar'daki astronotların uzay kıyafetlerinin ABD bayrağı ile donatılmış olması bu amaca yönelik önemli göstergelerden biridir. Filmdeki insanlığın geleneksel olarak doğaya karşı verdiği mücadeleyi kazanacağı miti de izleyiciye kabul ettirilmek istenmektedir. Kahraman Cooper'ın özellikle karadelikten kurtuluşunda bu mesajın kodlandığını görmek mümkündür. Kültürün (bilimin)uygarlığın, doğayı(uzayı)-barbarlığı galebe çalacağı (yeneceği) kodlanırken doğanın insanlığın en büyük düşmanı olarak betimlenen konumu korunmaktadır.

Ailenin kutsallığı ve bir aradalığı miti de filmde işlenilen temel yönlerden biridir. Kahraman Cooper'ın çocuklarını terk edip geri dönülmesi mümkün olmayan bir yolculuğa çıkması, bunun sonucunda da duyduğu vicdan azabı ve geriye dönmek istemesi, bir şekilde dönüşün yollarını araması da aile yapısının yeniden üretilmesi için gösterilen gayreti gözler önüne sermektedir. Nihayetinde, yaşlı Murphy’nin ölüm döşeğinde olduğu sahnede, tüm aile bir araya toplanır ve adeta kutsal kabul edilen 'şükran günü' gerçekleşir. Bunun gerçekleşmesi seyircinin-izler kitlenin talep ettiği bir şeydir: Hollywood ticari sineması ideal olan ahlaki yapıyı ve geleneksel Amerikan değerlerini birçok filmde yeniden ürettiği gibi bilim-kurgunun önemli filmleri arasına girmeye aday gösterilen 'Interstellar' da bundan kaçamamıştır.

Amerikan kültürünün önemli varyantlarında biri olan 'beyzbol' oyunu da filme ustaca yerleştirilmiştir. Bu kültürel değer filmin ideolojik temalarından birini oluştururken toz bulutunun gölgelediği beyzbol karşılaşmasının yarıda kesilmesi ise Amerikan toplumunun ürettiği 'depresyon yılları' mitiyle ilişkilendirilebilinir. Kahraman Cooper gözlerini açıp yaşadığını fark ettiği sahnede camdan (pencere de olabilir) dışarı baktığında bu sefer toz bulutsuz ama bir fanusun içinde beyzbol oynandığını görür. Yani, beyzbol olduğu sürece Amerika ve yaşam var olacaktır. Filmin son sahnesinde kahraman Cooper sayesinde, Dr. Amelia Brand'ın insanlığın yaşayabileceği bir gezegeni keşfettiği ortaya konulurken yırtılmış ve eskimiş ABD bayrağı gönderde dalgalanmaktadır, fetih gerçekleşmiştir. İnsanlar (ABD'liler) oraya göç edebilirler, ya da 'sömürgeleştirebilirler". Buradaki tema işlenirken sevgililerin buluşması güncel miti devreye girer ve masalsı bir sonla final yapılır.

\section{Sonuc}

Mitolojik destanlarda, halk hikâyelerinde ve masallarda olaylar çoğunlukla mutlu sonla bitmektedir. Bu bakımdan Interstellar her ne kadar 21.yüzyılın uzay-zaman tartışmalarını ve astrofiziğin teorik söylemlerini ve denklemlerini öykünün merkezine oturtsa da film, masallarda olduğu gibi herkesin istediği şekilde tamamlamaktadır. Hâlbuki, Interstellar filminin senaryosunu kaleme alan Jonathan Nolan ve filmin bilim danışmanı teorik fizikçi Kip Thorne'la yapılan bir röportajda filmin orijinal sonunun, esasında, bir felaketle noktalandığı belirtilmektedir. Nolan'ın yazdığı son Hollywood filmlerinin peri masalı şeklinde biçimlenen mutlu sonundan çok uzaktır. Orijinal senaryoya göre geçmişe mesaj göndermeye çalışan Cooper, Einstein-Rosen (iki evren arasında olduğu kabul edilen solucan deliği) köprüsünün yıkılmasıyla ölmektedir. Zamanı değiştirme ve eve dönüş gibi filmin sonunu süsleyen olayların hiç 
biri gerçek senaryoda bulunmamaktadır. Filmin gerçek sonu, gerçekleşmesi kesin olan kahraman Cooper'ın solucan deliği içerisinde ölmesi, kızı Murphy ile de iletişim kuramaması ve insanları kurtaracak denklemlerin hayata geçmemesi şeklindedir. Yani, gerçekte, filmin sonu bir felaketle bitmektedir. Gerek endüstriyel bir ürün olan ticari filmlerin güncel amaçları, gerekse bir anlatının temel biçimleri açısından filmin olası 'gerçek' sonuna müdahale edilmiştir. Kültür endüstrisinin dayattığı pratikler ve anlatının doyum ve katarsis olgusuyla yüzleşmesi nedeniyle filmin fizik denklemlerinin söylediği 'felaket' şeklinde değil; mutlu sonla bitirilmesi zorunlu olmuştur. Kuşkusuz filmlerin birer kurmaca anlatı olduğunu da unutmamak gerekir. Umberto Eco (1995:157-158), her ne olursa olsun kurmaca yapıtları okumaktan (izlemekten) vazgeçmeyeceğimizi; çünkü, onlarda yaşamımıza bir anlam verecek formülü aradığımızı belirtirken, yaşam boyunca neden dünyaya geldiğimizi ve yaşadığımızı söyleyecek bir ilk öykünün arayışı içinde olacağımıza vurgu yapar. Bu arayış, kimi zaman kozmik bir öykü, evrenin öyküsü, kimi zaman kendi bireysel öykümüzden oluşmaktadır.

\section{Kaynakça}

Barthes, Roland (2012). Göstergebilimsel Serüven. Çev., Mehmet Rifat\&Sema Rifat. İstanbul: Yapı Kredi.

Berger, Arthur Asa (2014). Kültür Eleştirisi: Kültürel Kavramlara Giriş. Çev.,Özgür Emir. İstanbul: Pinhan.

Bloom, Paul (2012). Hazzın Bilimi, Sevdiğimiz Şeyleri Neden Severiz. Çev.,Ahmet Birsen. İstanbul: Alfa.

Eco, Umberto (1995). Anlatı Ormanlarında Altı Gezinti. Çev., Kemal Aktay. İstanbul: Can.

Erkman Akerson, Fatma (2005). Göstergebilime Giriş. İstanbul: Multilingual.

Fiske, John (2003). Iletişim Çalışmalarına Giriş. Çev., Süleyman İrvan. Ankara: Bilim ve Sanat

Parsa, Alev (2012). Sinema Göstergebiliminde Yapısal Çözümleme: Sinemasal Anlatı Sunumu ve Kodlar. Görsel Metin Çözümleme: İletişim Bilimlerinde Araştırma Yöntemleri içinde (11-33). Özlem Güllüoğlu (der.) Ankara: Ütopya.

Postman, Neil (2004). Televizyon Öldüren Eğlence, Gösteri Çağında Kamusal Söylem. Çev., Osman Akınhay. İstanbul: Ayrıntı.

Propp, Jakovlevitch Vladimir (1987). Masalların Yapısı ve İncelenmesi. Çev., Hüseyin Gümüş. Ankara: Kültür ve Turizm Bakanlığı.

Propp, Jakovlevitch Vladimir(1995). "Olağanüstü Masalların Dönüşümleri” Yazın Kuramı, Rus Biçimcilerin Metinleri. Tzvetan Todorov (der.) içinde. Çev.Mehmet Rifat \& Sema Rifat. İstanbul: Yapı Kredi.

Ricceur, Paul (2012). Zaman ve Anlatı: Üç, Kurmaca Anlatıda Zamanın Biçimlenişi. Çev., Mehmet Rifat. İstanbul: Yapı Kredi. 
Todorov, Tzvetan (2014). Poetikaya Giriş. Çev., Kaya Şahin. İstanbul: Metis.

Yaren, Özgür(2013).Sinemada Anlatı Kuramı. Zeynep Özarslan(der) içinde. Beyazperdeyi Aydınlatan Kuramlar: Sinema Kuramları-2 içinde (167-192). İstanbul: Su.

Yücel, Tahsin (2008). Yapısalcılık. İstanbul: Can.

Zariç, Mahfuz (2013). "Vladimir Propp'un İşlevler ve Eylem Alanları Modeli Açısından Yaşar Kemal'in Ağrı Dağı Efsanesi Romanı." Hece 195: (108-117).

http://www.kurgu-bilim.com/Interstellar-yildizlararasi/, 03 Mayıs 2015.

http://incil.info/arama/Yuhanna+11:38-44, İncil - Yeni Çeviri 2009, 06 Mayıs 2015.

http://en.wikipedia.org/wiki/Gargantua_and_Pantagruel\#Gargantua, 03 Mayıs 2015.

http://www.mythencyclopedia.com/Ca-Cr/Corn.html, 03 Mayıs 2015.

http://tr.wikipedia.org/wiki/Y\%C4\%B1ld\%C4\%B1zlararas\%C4\%B1, 21 Ağustos 2015

http://hayrabolutb.org.tr/media/ziraat/Misir-Tarimi-2.pdf, 21 Ağustos 2015.

https://tr.wikipedia.org/wiki/Dust_Bowl, 21 Ağustos 2015.

https://tr.wikipedia.org/wiki/Kronos, 11 Eylül 2015. 